\title{
Fluid flow regimes and growth of a giant pockmark
}

\author{
Yann Marcon ${ }^{1}$, Hélène Ondréas ${ }^{2}$, Heiko Sahling ${ }^{1}$, Gerhard Bohrmann ${ }^{1}$ and Karine Olu ${ }^{3}$ \\ ${ }^{1}$ MARUM, University of Bremen, Leobener Str., 28359 Bremen, Germany \\ ${ }^{2}$ IFREMER, Centre de Bretagne, REM/GM, 29280 Plouzané, France \\ ${ }^{3}$ IFREMER, Centre de Bretagne, REM/EEP, 29280 Plouzané, France
}

\begin{abstract}
:
Pockmarks are seafloor depressions commonly associated with fluid escape from the seabed and are believed to contribute noticeably to the transfer of methane into the ocean and ultimately into the atmosphere. They occur in many different areas and geological contexts, and vary greatly in size and shape. Nevertheless, the mechanisms of pockmark growth are still largely unclear. Still, seabed methane emissions contribute to the global carbon budget, and understanding such processes is critical to constrain future quantifications of seabed methane release at local and global scales. The giant Regab pockmark $\left(9^{\circ} 42.6^{\prime} \mathrm{E}, 5^{\circ} 47.8^{\prime} \mathrm{S}\right)$, located at $3160 \mathrm{~m}$ water depth near the Congo deep-sea channel (offshore southwestern Africa), was investigated with state-of-the-art mapping devices mounted on IFREMER's (French Research Institute for Exploitation of the Sea) remotely operated vehicle (ROV) Victor 6000. ROV-borne micro-bathymetry and backscatter data of the entire structure, a high-resolution photo-mosaic covering $105,000 \mathrm{~m}^{2}$ of the most active area, sidescan mapping of gas emissions, and maps of faunal distribution as well as of carbonate crust occurrence are combined to provide an unprecedented detailed view of a giant pockmark. All data sets suggest that the pockmark is composed of two very distinctive zones in terms of seepage intensity. We postulate that these zones are the surface expression of two fluid flow regimes in the subsurface: focused flow through a fractured medium and diffuse flow through a porous medium. We conclude that the growth of giant pockmarks is controlled by self-sealing processes and lateral spreading of rising fluids. In particular, partial redirection of fluids through fractures in the sediments can drive the pockmark growth in preferential directions.
\end{abstract}

\section{Introduction}

Pockmarks are seafloor depressions considered to be the surficial expressions of fluid seepage processes, as well as mud volcanoes or gas hydrate pingoes (Judd and Hovland, 2007; Serié et al., 2012). However, pockmark morphologies, sizes and densities vary greatly, suggesting that the term "pockmark" is loosely constrained and applies to a broad range of seafloor features (King and MacLean, 1970; Hovland et al., 2002; Judd and Hovland, 2007; Gay et al., 2007).

The shape of a pockmark is the result of local conditions and the processes involved in the formation and growth of pockmarks are likely to vary between settings. Several formation mechanisms have been proposed that involve either slow and continuous processes (Hovland et al., 1984; Harrington, 1985; Sultan et al., 2010) or more rapid and sudden events (MacDonald et al., 1994; Hovland et al., 2005). All the different hypotheses confirm that several processes could apply and that the main 
mechanisms involved in the formation and growth of pockmarks remain largely unclear. A better knowledge of these processes is crucial to strengthen our understanding of the dynamics of methane release from the seabed into the ocean.

In this study we present for the first time the results of high-resolution acoustic and optical surveys of the giant Regab pockmark in the lower Congo basin. Surveys were conducted using the Ifremer's remotely operated vehicle (ROV) Victor 6000 during the West African Cold Seeps (WACS) cruise on the RV Pourquoi Pas? in January-February 2011. The data set is fully 
Publisher: GSA

Journal: GEOL: Geology

Article ID: G34801

47 comprehensive and includes in particular ROV-borne micro-bathymetry and backscatter maps of

48 the entire pockmark together with detailed sidescan-based mapping of seafloor gas emissions.

49 This is completed by a $105,000 \mathrm{~m}^{2}$-large high-resolution photo-mosaic and fauna mapping of the

50 most populated and active area of the pockmark in terms of seepage intensity.

51 To date, such a comprehensive data set of a pockmark feature is unique and gives

52 unprecedented insights on the detailed morphology of complex pockmarks. In particular, the

53 results provide valuable clues to decipher the functioning of giant pockmarks, which are

54 discussed in this study.

55 STUDY AREA

The Regab pockmark is located on the Gabon-Congo-Angola margin $\sim 10 \mathrm{~km}$ north of the

57 Congo channel at $\sim 3160$ m water depth (Ondréas et al., 2005). In this area, muddy hemipelagic

58 sediments cover turbiditic channel/levee bodies of the Congo fan (Droz et al., 1996; Gay et al.,

59 2003). Seismic data show that the pockmark is linked to a deep palaeochannel/levee system that

60 could act as reservoir for the seeping fluids. Advecting fluids are enriched in methane of

61 biogenic origin (Charlou et al., 2004) and sustain an abundant population of chemosynthetic

62 fauna (Olu-Le Roy et al., 2007) within the pockmark. Crusts of authigenic carbonates are

63 extensive (Ondréas et al., 2005; Pierre and Fouquet, 2007) and widespread presence of shallow

64 gas hydrates was inferred from seafloor observations and sediment cores (Charlou et al., 2004;

65 Olu-Le Roy et al., 2007; Pierre et al., 2012).

66 DATA AND METHODS

67 Bathymetry data were acquired with a multibeam echosounder (MBES) Reson Seabat

687125 running at $400 \mathrm{kHz}$. The main survey was conducted from $30 \mathrm{~m}$ altitude over a $1.2 \mathrm{~km}^{2}$ -

69 large area and allowed to map the entire pockmark. An additional survey was conducted from 8 
Publisher: GSA

Journal: GEOL: Geology

Article ID: G34801

70 m altitude over a $0.175 \mathrm{~km}^{2}$-large subarea of the pockmark. The data was processed with

71 CARAIBES (Le Gal and Edy, 1997) and the final bathymetry and backscatter maps include both

72 data sets with a $25 \mathrm{~cm}$ resolution.

73 Imagery data were acquired simultaneously to the second bathymetry survey with the

74 Victor 6000's high sensitivity OTUS photo-camera, and the photomosaic was constructed using

75 the ROV navigation with LAPM Tool (Marcon et al., 2013a). Therefore, an excellent match of

76 the photomosaic onto the bathymetry was obtained. The mosaic was used to map the carbonate

77 precipitates and the fauna distribution. Mapped fauna include siboglinid polychaetes

78 (tubeworms), bathymodiolid mussels and vesicomyid clams.

79 Seabed gas emissions in the water column were mapped using the CARIS program to

80 visualize the sidescan data. Sidescan data allowed us to identify the presence of gas in the water

81 column as far as $30 \mathrm{~m}$ on each side of the ROV. Due to the dense track line spacing, $86 \%$ of the

82 pockmark was mapped. Finally, the presence of gas emissions and outcropping hydrates on the

83 seafloor was confirmed using dive videos.

\section{RESULTS}

\section{Bathymetry}

86 The bathymetry (Fig. 1) shows that the pockmark is a large elliptical structure with

87 diameters ranging between 700 and $950 \mathrm{~m}$. It stretches in the N70 direction along an elongated

88 feature, possibly related to a fracture. Elongated appendices can be observed in several places at

89 the edge of the pockmark. The largest of these occur in the northeastern side and seem to be

90 extensions of the N70 fracture expression. The pockmark boundary shows a sharp edge in the

91 northeastern half, and becomes softer toward the southwestern side. The bathymetry also reveals 
Publisher: GSA

Journal: GEOL: Geology

Article ID: G34801

92 that Regab is composed of numerous ( $>1000)$ rounded depressions, or sub-pockmarks, of various

93 sizes (from less than $5 \mathrm{~m}$ to $100 \mathrm{~m}$ in diameter) and depths (from 0.5 to $15 \mathrm{~m}$ ).

94 Those depressions are not randomly distributed and two zones can be clearly

95 distinguished (Fig. 1): zone 1 is composed of relatively large ( $>20 \mathrm{~m})$ and deep ( $>3 \mathrm{~m})$ sub-

96 pockmarks, and is characterized by a very rugged surface and the presence of carbonate

97 elevations and slabs; zone 2 has a smoother appearance but is scattered by more than a thousand

98 very small $(<5 \mathrm{~m})$ to medium-sized (up to $60 \mathrm{~m}$ ) and shallow $(<3 \mathrm{~m})$ pits, also known as unit

99 pockmarks.

100 Backscatter and Gas Plumes

101 The signal reflectivity and gas plume distribution show a very characteristic pattern over

102 the pockmark area (Fig. 1). Zone 1 is almost entirely characterized by high-backscatter

103 reflectivity areas. The largest of them is located around the N70 longitudinal feature identified on

104 the bathymetry; it stretches up to and along the eastern edge of Regab. Two additional areas of

105 high backscatter occur precisely on the boundary of the pockmark, respectively on the northern

106 and southern edges; they are associated with distinct and relatively large sub-pockmarks (80-100

$107 \mathrm{~m}$ in diameter). Zone 2 has a comparatively low-backscatter signature, but is scattered by a

108 myriad of high-reflectivity anomalies of various sizes (up to $50 \mathrm{~m}$ in width) and shapes; these

109 anomalies are consistently located within the numerous shallow unit pockmarks identified from

110 the bathymetry. Vice versa, zone 2 unit pockmarks are always associated with high-reflectivity

111 anomalies. Gas emissions occurred exclusively within the largest high-reflectivity area of zone 1.

\section{OTUS and Video Imagery}

113 The faunal and carbonate mapping from the photomosaic reveals a clear segregation

114 between zones 1 and 2, and a clear causal link with backscatter data (Fig. 2). 
Publisher: GSA

Journal: GEOL: Geology

Article ID: G34801

115 The rugged morphology of zone 1 is shaped by massive carbonate crusts that form thick

116 elevations around sediment-covered depressions. Gas hydrates occur at the surface in several

117 places (Fig. 1) under carbonate crusts. Near the most active areas in terms of gas emissions,

118 carbonate elevations host abundant mussel and tubeworm populations (Fig. 1-2). Generally,

119 mussel beds are located closer to active gas emissions and in areas of disturbed seafloor, where

120 carbonate crusts seem broken or displaced. Clams are generally distributed in sediment-covered

121 areas of negative relief, but rarely within the deepest depressions of zone 1. Conversely,

122 carbonate crusts, mussels and tubeworms are never observed in zone 2, and the imagery data

123 (photomosaic + dive videos) only reveals soft sediments and clams presence. However, the clam

124 distribution in zone 2 is very distinctive and shows that clams are only present in the center of

125 the unit pockmarks, precisely where the zone 2 high reflectivity anomalies occur (Fig. 2).

126 DISCUSSION

127 Previous studies showed that the activity at Regab is linked to the presence of a vertical

128 chimney under the pockmark that is rooted into a palaeo-channel (Ondréas et al., 2005; Gay et

129 al., 2006b) and that the advection of fluid through the gas hydrate stability zone is possibly

130 related to a fault (Gay et al., 2006a). Such interpretation is supported by the elliptical shape of

131 the pockmark and the linear feature evidenced from the bathymetry (Fig. 1). However, although

132 a fracture is likely the main feature controlling the fluid expulsion pattern at Regab, the new

133 high-resolution data revealed two very distinctive zones within the pockmark. These two zones

134 show striking differences and are clearly the expressions of very distinct fluid flow regimes and

135 formation mechanisms.

136 Zone 1: Intense and Focused Fluid Flow 
Publisher: GSA

Journal: GEOL: Geology

Article ID: G34801

Thick carbonate elevations, rich fauna and intense gas venting are clear indications for

138 high, focused and long-term seepage activity. First, the abundance of thick crusts of authigenic

139 carbonates at the surface suggests that the anaerobic oxidation of methane (AOM) occurs close

140 to the sediment surface (Aloisi et al., 2002) and has been active for a long period of time (Luff

141 and Wallmann, 2003). A shallow AOM front would therefore indicate an intense upward flux of

142 methane from below (Borowski et al., 1999). Next, patterns in the distribution of mussels and

143 tubeworms (Olu-Le Roy et al., 2007 and Figure 2b-c) indicate that the chemical fluxes are

144 heterogeneous across the zone. In particular, mussels and gas emissions were often observed

145 together. Marcon et al. (2013b) showed that mussel occurrence at Regab reflect areas of intense

146 fluid flow, where chemical supply is locally high. Finally, the faunal distribution (Ondréas et al.,

147 2005), the backscatter signal and the overall shape of zone 1 show a strong correlation with the

148 N70 axis identified from the bathymetry. It is likely that such discontinuity provides the main

149 pathways for focused fluid flow in this zone.

150 The formation of zone 1 topography is not yet fully understood but seafloor observations

151 showed that gas emissions and outcropping hydrates occur in areas of broken crusts or of

152 displaced blocs; such features are evidence for catastrophic events, and are likely related to

153 sudden release of pressured free gas from under the crusts (Hovland et al., 2005) and to rafting of

154 gas hydrates deposits (MacDonald et al., 1994).

\section{Zone 2: Diffuse and Homogeneous Fluid Flow}

156 Carbonates, gas escape and hard substratum fauna were not observed in zone 2. Instead,

157 hundreds of small and medium shallow sub-pockmarks populated by clams scatter the zone (Fig.

158 1-2). We postulate that the relatively smooth surface of zone 2 is the expression of a more

159 diffuse and uniform fluid flow pattern than in zone 1. This is supported by previous works in the 
Publisher: GSA

Journal: GEOL: Geology

Article ID: G34801

160 Congo basin that correlated the distribution of clams to transient and low seepage activity areas

161 (Olu-Le Roy et al., 2007; Sahling et al., 2008; Marcon et al., 2013b).

162 The formation of those sub-pockmarks could be related to various mechanisms such as:

163 sediment lifting by ascending gas (Hovland et al., 1984), pore fluid drainage (Harrington, 1985;

164 Hovland et al., 2010), rafting of hydrate clumps (MacDonald et al., 1994), or hydrate dissolution

165 (Sultan et al., 2010). A mechanism involving free gas escape in this zone is, however, not

166 supported by the gas emission mapping. In addition, mechanisms involving the presence of

167 shallow gas hydrate deposits are not supported by backscatter data and the observed scarcity of

168 faunal communities (Fig. 1-2), which suggests low seepage activity. However, pore fluid

169 advection does occur at Regab, with rates up to $2.3 \mathrm{~mm} / \mathrm{a}$ at the western edge of the pockmark

170 (Chaduteau et al., 2009). This favors the models by Harrington (1985) and Hovland et al. (2010),

171 according to which advecting pore water is retained in fine sediments until it is released due to

172 water or gas-triggered pressure buildup. Subsequent sediment winnowing and water drainage

173 ultimately leads to the formation of pits, or unit pockmarks, at the surface.

174 Possible Mechanisms Controlling the Pockmark Growth

175 We propose that self-sealing processes and subsequent fluid flow redirection control the

176 pockmark growth (Fig. 3). By causing sediment permeability to decrease, the formation of

177 authigenic carbonates may ultimately form a natural seal for rising fluids (Hovland, 2002).

178 Assuming non-decreasing seepage intensity, a pore-pressure increase would lead excess fluids to

179 spread laterally until sufficient pathways to the sediment surface become available and that

180 uniform flow at hydrostatic pressure is restored. This is similar to the concept of 'shortest and

181 most permeable vertical pathway' used to explain the migration of petroleum fluids in rocks and

182 sediments (Mackenzie and Quigley, 1988; Floodgate and Judd, 1992). 
Publisher: GSA

Journal: GEOL: Geology

Article ID: G34801

Redirected fluids may transit as diffuse flow through non-fractured porous sediments or

184 as focused flow along sediment discontinuities. Regab provides evidences for both: mainly

185 focused flow in zone 1 and diffuse flow in zone 2. Results suggest that rising fluids in zone 1

186 were partly redirected through fractures or discontinuities within the sediments, thus leading the

187 pockmark growth into the N70 preferential direction. In the absence of similar preferential fluid

188 pathways, fluid flow in zone 2 spreads over a relatively large area and reaches the surface in a

189 more isotropic way and with a lower intensity than in zone 1.

190 CONCLUSION

191 This is the first study to present such a high resolution and comprehensive mapping data

192 set of an entire giant complex pockmark. It demonstrates that current modern techniques exist

193 that allow for detailed and large-scale investigations of the deep-seafloor. The value of such

194 comprehensive data sets goes beyond the mere production of high quality maps. By giving full

195 sight of the area of study it allows getting a deeper understanding of the system and the long-

196 term processes involved. In this study, it allowed identifying zones with distinct fluid flow

197 regimes, and constraining growth mechanisms for giant pockmarks. These findings on pockmark

198 dynamics constitute a base model to orientate future work and constrain assessments of seabed

199 methane fluxes at giant pockmarks.

200 ACKNOWLEDGMENTS

201 We would like to thank the captain and crew of RV Pourquoi Pas? and ROV Victor

202 6000. Also thanks to Olivier Soubigou for his help onboard, to Alain Normand for processing

203 the micro-bathymetry, and to James Collins for proofreading the manuscript. This work was

204 supported by the Ifremer and by SENSEnet, a Marie Curie Initial Training Network (ITN) 
Publisher: GSA

Journal: GEOL: Geology

Article ID: G34801 2009-237868.

207

208

209

210

211

212

213

214

215

216

217

218

219

220

221

222

223

224

225

226

227

\section{REFERENCES CITED}

Aloisi, G., Bouloubassi, I., Heijs, S.K., Pancost, R.D., Pierre, C., Sinninghe Damsté, J.S., Gottschal, J.C., Forney, L.J., and Rouchy, J.M., 2002, CH4-consuming microorganisms and the formation of carbonate crusts at cold seeps: Earth and Planetary Science Letters, v. 203, p. 195-203, doi:10.1016/S0012-821X(02)00878-6.

Borowski, W.S., Paull, C.K., and Ussler, W., III, 1999, Global and local variations of interstitial sulfate gradients in deep-water, continental margin sediments: Sensitivity to underlying methane and gas hydrates: Marine Geology, v. 159, no. 1-4, p. 131-154, doi:10.1016/S0025-3227(99)00004-3.

Chaduteau, C., Jean-Baptiste, P., Fourré, E., Charlou, J.L., and Donval, J.P., 2009, Helium transport in sediment pore fluids of the Congo-Angola margin: Geochemistry Geophysics Geosystems, v. 10, Q01002, doi:10.1029/2007GC001897.

Charlou, J.L., Donval, J.P., Fouquet, Y., Ondréas, H., Knoery, J., Cochonat, P., Levaché, D., Poirier, Y., Jean-Baptiste, P., Fourré, E., and Chazallon, B., 2004, Physical and chemical characterization of gas hydrates and associated methane plumes in the Congo-Angola Basin: Chemical Geology, v. 205, p. 405-425, doi:10.1016/j.chemgeo.2003.12.033.

Droz, L., Rigaut, F., Cochonat, P., and Tofani, R., 1996, Morphology and recent evolution of the Zaire turbidite system (Gulf of Guinea): Geological Society of America Bulletin, v. 108, p. 253-269, doi:10.1130/0016-7606(1996)108<0253:MAREOT>2.3.CO;2.

Floodgate, G.D., and Judd, A.G., 1992, The origins of shallow gas: Continental Shelf Research, v. 12, p. 1145-1156, doi:10.1016/0278-4343(92)90075-U. 
Publisher: GSA

Journal: GEOL: Geology

Article ID: G34801

228 Gay, A., Lopez, M., Cochonat, P., Sultan, N., Cauquil, E., and Brigaud, F., 2003, Sinuous

229 pockmark belt as indicator of a shallow buried turbiditic channel on the lower slope of the

230 Congo basin, West African margin: Geological Society of London Special Publication 216,

231 p. 173-189, doi:10.1144/GSL.SP.2003.216.01.12.

232 Gay, A., Lopez, M., Cochonat, P., Levaché, D., Sermondadaz, G., and Seranne, M., 2006a,

233 Evidences of early to late fluid migration from an upper Miocene turbiditic channel revealed

234 by 3D seismic coupled to geochemical sampling within seafloor pockmarks, Lower Congo

235 Basin: Marine and Petroleum Geology, v. 23, no. 3, p. 387-399,

236 doi:10.1016/j.marpetgeo.2006.02.004.

237 Gay, A., Lopez, M., Ondréas, H., Charlou, J.L., Sermondadaz, G., and Cochonat, P., 2006b,

238 Seafloor facies related to upward methane flux within a Giant Pockmark of the Lower

239 Congo Basin: Marine Geology, v. 226, p. 81-95, doi:10.1016/j.margeo.2005.09.011.

240 Gay, A., Lopez, M., Berndt, C., and Séranne, M., 2007, Geological controls on focused fluid

241 flow associated with seafloor seeps in the Lower Congo Basin: Marine Geology, v. 244,

242 p. 68-92, doi:10.1016/j.margeo.2007.06.003.

243 Harrington, P., 1985, Formation of pockmarks by pore-water escape: Geo-Marine Letters, v. 5,

244 p. 193-197, doi:10.1007/BF02281638.

245 Hovland, M., 2002, On the self-sealing nature of marine seeps: Continental Shelf Research, v. 22, p. 2387-2394, doi:10.1016/S0278-4343(02)00063-8.

247 Hovland, M., Judd, A.G., and King, L.H., 1984, Characteristic features of pockmarks on the

248 North Sea Floor and Scotian Shelf: Sedimentology, v. 31, p. 471-480, doi:10.1111/j.1365-

$249 \quad$ 3091.1984.tb01813.x. 
Publisher: GSA

Journal: GEOL: Geology

Article ID: G34801

250 Hovland, M., Gardner, J.V., and Judd, A.G., 2002, The significance of pockmarks to understanding fluid flow processes and geohazards: Geofluids, v. 2, p. 127-136, doi:10.1046/j.1468-8123.2002.00028.x.

253

254

255

256

257

258

259

260

261

262

263

264

265

266

267

268

269

270

271

Hovland, M., Svensen, H., Forsberg, C.F., Johansen, H., Fichler, C., Fosså, J.H., Jonsson, R., and Rueslåtten, H., 2005, Complex pockmarks with carbonate-ridges off mid-Norway: Products of sediment degassing: Marine Geology, v. 218, p. 191-206, doi:10.1016/j.margeo.2005.04.005.

Hovland, M., Heggland, R., De Vries, M.H., and Tjelta, T.I., 2010, Unit-pockmarks and their potential significance for predicting fluid flow: Marine and Petroleum Geology, v. 27, p. 1190-1199, doi:10.1016/j.marpetgeo.2010.02.005.

Judd, A.G., and Hovland, M., 2007, Seabed Fluid Flow: The Impact of Geology, Biology and the Marine Environment: Cambridge, UK, Cambridge University Press, 492 p.

King, L.H., and MacLean, B., 1970, Pockmarks on the Scotian Shelf: Geological Society of America Bulletin, v. 81, p. 3141-3148, doi:10.1130/00167606(1970)81[3141:POTSS]2.0.CO;2.

Le Gal, L., and Edy, C., 1997, CARAIBES: An integrated software for multibeam echosounder and sidescan sonar data mapping, in OCEANS '97: MTS/IEEE Conference Proceedings, p. $1242-1245$.

Luff, R., and Wallmann, K., 2003, Fluid flow, methane fluxes, carbonate precipitation and biogeochemical turnover in gas hydrate-bearing sediments at Hydrate Ridge, Cascadia Margin: Numerical modeling and mass balances: Geochimica et Cosmochimica Acta, v. 67, p. 3403-3421, doi:10.1016/S0016-7037(03)00127-3. 
Publisher: GSA

Journal: GEOL: Geology

Article ID: G34801

272 MacDonald, I.R., Guinasso, N.L., Sassen, R., Brooks, J.M., Lee, L., and Scott, K.T., 1994, Gas

273 hydrate that breaches the sea floor on the continental slope of the Gulf of Mexico: Geology,

274 v. 22, p. 699-702, doi:10.1130/0091-7613(1994)022<0699:GHTBTS>2.3.CO;2.

275 Mackenzie, A.S., and Quigley, T.M., 1988, Principles of Geochemical Prospect Appraisal:

276 American Association of Petroleum Geologists Bulletin, v. 72, p. 399-415.

277 Marcon, Y., Sahling, H., and Bohrmann, G., 2013a, LAPM: A tool for underwater large-area 278 photo-mosaicking: Geoscientific Instrumentation: Methods and Data Systems, v. 2, p. 189279 198, doi: 10.5194/gi-2-189-2013.

280 Marcon, Y., Sahling, H., Allais, A.G., Bohrmann, G., and Olu-Le Roy, K., 2013b, Distribution 281 and temporal variation of mega-fauna at the Regab pockmark (Northern Congo Fan), based on a comparison of videomosaics and GIS analyses: Marine Ecology,

Olu-Le Roy, K., Caprais, J.C., Fifis, A., Fabri, M.C., Galéron, J., Budzinsky, H., Le Ménach, K., 285 Khripounoff, A., Ondréas, H., and Sibuet, M., 2007, Cold-seep assemblages on a giant

Ondréas, H., and 13 others, 2005, ROV study of a giant pockmark on the Gabon continental margin: Geo-Marine Letters, v. 25, p. 281-292, doi:10.1007/s00367-005-0213-6.

290 Pierre, C., and Fouquet, Y., 2007, Authigenic carbonates from methane seeps of the Congo deepsea fan: Geo-Marine Letters, v. 27, p. 249-257, doi:10.1007/s00367-007-0081-3.

292 Pierre, C., Blanc-Valleron, M.M., Demange, J., Boudouma, O., Foucher, J.P., Pape, T., Himmler, 293 T., Fekete, N., and Spiess, V., 2012, Authigenic carbonates from active methane seeps 
Publisher: GSA

Journal: GEOL: Geology

Article ID: G34801

$295 \quad \mathrm{x}$.

296 Sahling, H., Bohrmann, G., Spiess, V., Bialas, J., Breitzke, M., Ivanov, M., Kasten, S., Krastel,

297 S., and Schneider, R., 2008, Pockmarks in the Northern Congo Fan area, SW Africa:

298 Complex seafloor features shaped by fluid flow: Marine Geology, v. 249, p. 206-225, 299 doi:10.1016/j.margeo.2007.11.010.

300 Serié, C., Huuse, M., and Schødt, N.H., 2012, Gas hydrate pingoes: Deep seafloor evidence of 301 focused fluid flow on continental margins: Geology, v. 40, p. 207-210, 302 doi:10.1130/G32690.1.

303 Sultan, N., Marsset, B., Ker, S., Marsset, T., Voisset, M., Vernant, A.M., Bayon, G., Cauquil, E., 304 Adamy, J., Colliat, J.L., and Drapeau, D., 2010, Hydrate dissolution as a potential 305 mechanism for pockmark formation in the Niger delta: Journal of Geophysical Research, 306 v. 115, B08101, doi:10.1029/2010JB007453. 
Publisher: GSA

Journal: GEOL: Geology

Article ID: G34801
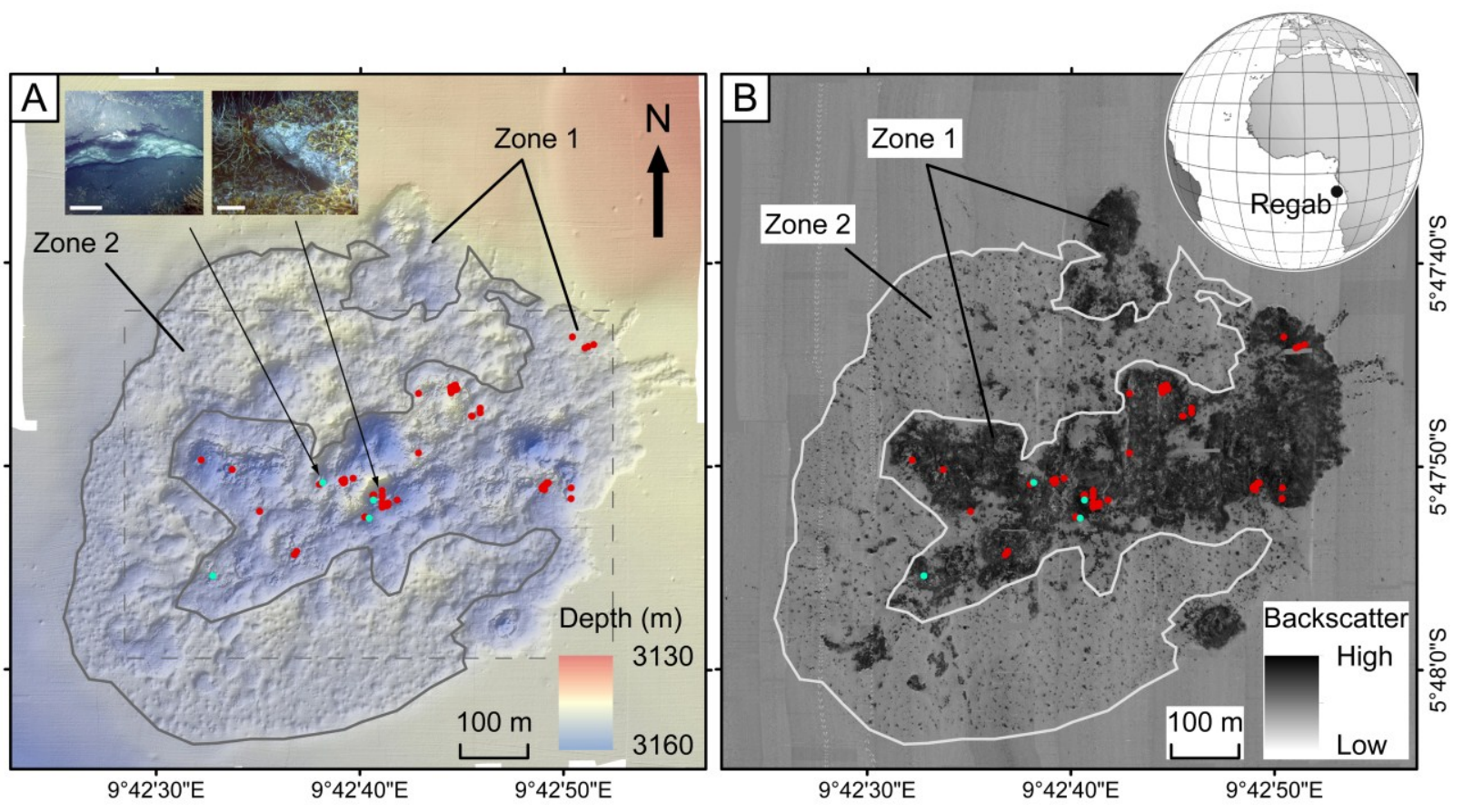

311 Figure 1. (A) Micro-bathymetry and (B) backscatter intensity of the Regab pockmark. Seabed

312 gas emissions (red dots) were identified from both sidescan and video data. Gas hydrate outcrops

313 (blue dots) were identified from video data only. The globe view shows the location of the Regab

314 pockmark. The image insets show hydrate outcrops under broken/tilted carbonate blocks,

315 mussels and tubeworms (scale bar represents $50 \mathrm{~cm}$ ). Zone 1 is characterized by a rugged surface

316 with large $(>20 \mathrm{~m})$ and deep (>3 m) depressions, strong backscatter signature, gas emissions and

317 gas hydrates at outcrop; zone 2 has a smoother appearance with comparatively low backscatter

318 signature; it is scattered by numerous $(>1000)$ shallow $(<3 \mathrm{~m})$ depressions, however, gas

319 emission sites and hydrate outcrops have not been observed. The dashed rectangle in A shows

320 the extent of Figure 2. 
Publisher: GSA

Journal: GEOL: Geology

Article ID: G34801

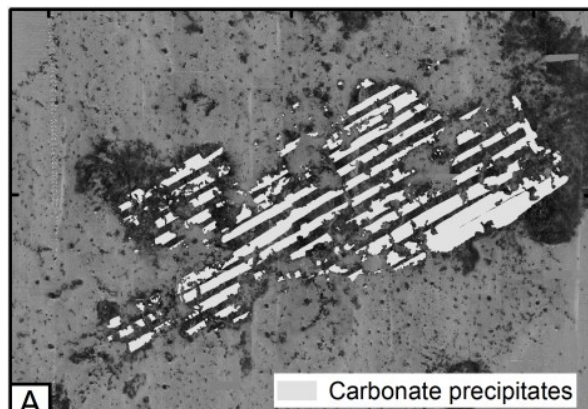

323 Figure 2. A: Carbonate distribution and backscatter in the center of Regab; the carbonate

324 precipitates cause most high-backscatter anomalies. B: Fauna distribution and backscatter;

325 tubeworms and mussels occur in areas where high-backscatter is caused by carbonate

326 precipitates; clam shells generate high-backscatter anomalies unrelated to precipitates. C: Fauna

327 distribution and micro-bathymetry; tubeworms and mussels occur mainly on elevated areas;

328 clams are present in lower areas, but rarely in the deepest depressions. B and C: Inserts represent

329 magnifications of the same area (black rectangles) of zone 2. The mosaic was constructed with

330 the LAPM tool (Marcon et al., 2013a) by geo-referencing individual images with the ROV

331 navigation data. 
Publisher: GSA

Journal: GEOL: Geology

Article ID: G34801

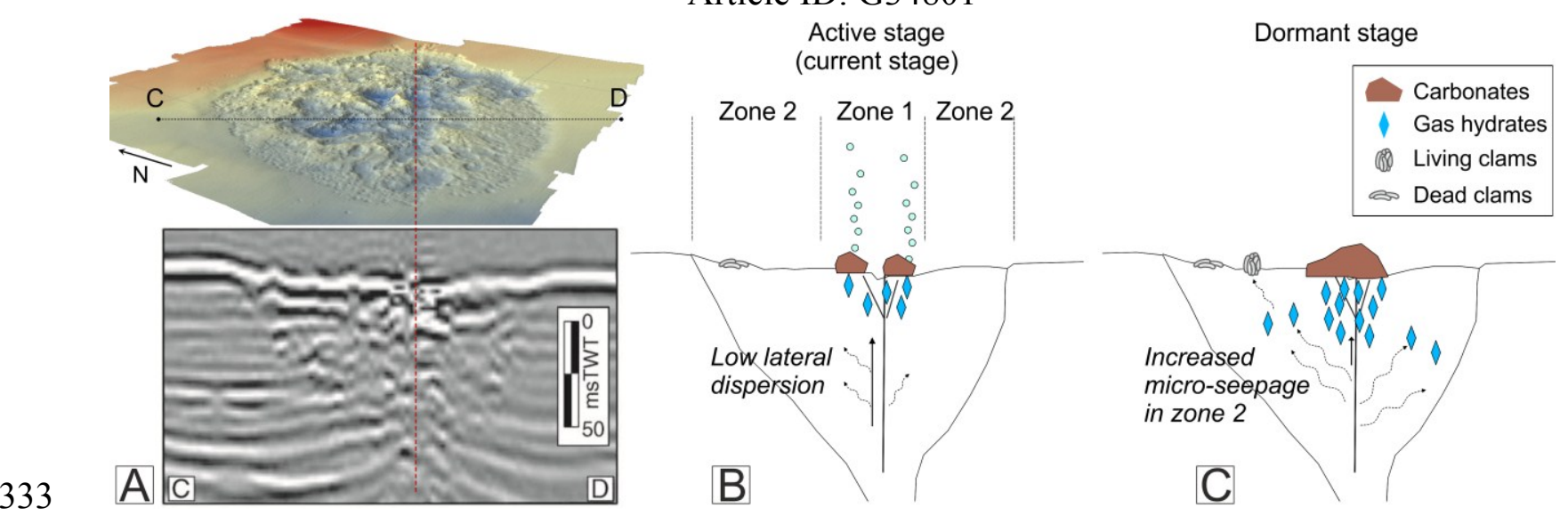

334 Figure 3. Plumbing system of Regab. A: The surficial fracture expression of zone 1 is located

335 right above the main seismic chimney. B: Schematic of Regab in its current active stage; seepage

336 is driven along focused pathways, leading to carbonate formation, shallow hydrates, gas escape

337 and abundant fauna in zone 1. C: Given time, carbonates and hydrate deposits cause sediment

338 vertical permeability to decrease and rising fluids to redirect and spread within surrounding

339 sediments. Seismic data after Gay et al. (2006b). 